\title{
PSYCHE
}

\begin{tabular}{lll}
\hline Vol. LI & SePt.-Dec., 1944 & Nos. 3-4 \\
\hline
\end{tabular}

\section{SYSTEMATIC NOTES ON THE GENUS PSEUDOMYRMA ${ }^{1}$}

\author{
By E. V. Enzmann ${ }^{2}$ \\ The Haskins Laboratory
}

The genus Pseudomyrma is one of the most difficult of the genera of the family Formicidæ and few systematists have attempted to explore the intricacies of its classification.

The genus was created by Latreille, 1831; up to the middle of the past century only a few forms were known of which Fabricius described two and Guérin and Spinola each contributed two more. The genus began to suffer from a sort of abnormal growth due to the writings of $\mathrm{F}$. Smith who added some forty new forms, most of them badly characterized. In one case Smith illustrated the description of a Pseudomyrma with the drawing of an Eciton. The resultant chaos discouraged many later writers, a fact which can be readily seen by a perusal of the small list of later contributors. Thus, Mayr described 7 forms, Roger 4, Emery 15, Forel 78, Wheeler 6 and Santschi 16. In addition, Buckley, Norton, Wasmann and Aquayo each described one; Mann and Sitz described two each, and Wheeler in collaboration with Mann added four more.

Through the kindness of Professor Banks, Curator of the Entomological Collections of the Museum of Comparative Zoölogy, Harvard University, we are in the fortunate position of having access to the large collection, which is mainly built around Wheeler's material; many of the types and identified specimens are available here.

The Haskins Collection contains an additional number of

${ }^{1}$ Published with the aid of a grant from the Museum of Comparative Zoölogy at Harvard College.

${ }^{2}$ Mailing address: The Biological Laboratories, Harvard University. 
types and identified specimens. The two collections between them contain specimens of nearly half of all the described species and varieties.

Following Forel's example we have disregarded a number of inadequately described forms, mostly those of F. Smith. Forel's viewpoint on Smith's work is given in the following quotation:

"F. Smith hat eine grosse Anzahl Arten dieser Gattung (Pseudomyrma) moeglichst oberflaechlich, fast ausschliesslich nach der bei den verschiedenen Individuen ungemein variierenden Farbe beschrieben. Es folgt daraus, dass die Mehrzahl seiner Arten unentwirrbar ist. Was bis jetzt entraetselt werden konnte ist von Mayr, Emery und mir klargestellt worden. Den Rest muss man ignorieren, oder man muss auf die Beschreibung und Neubenennung von Pseudomyrmaarten verzichten. Ich will nun das erstere tun."

Emery, 1895-1897, Zool. Jb. Syst., expresses similar views.

Forel however can not be absolved from adding to the difficulties of the systematics of Pseudomyrma. He described a very large number of new forms, mostly subspecies and varieties, based on minute differences, but failed to arrange his and the previously described forms and integrate them into a system. He was able to do this only because of his remarkable knowledge, which prevented him from making mistakes and duplications.

Emery in his catalogue (Gen. Ins. 1921-23) made some attempt to arrange the known forms of Pseudomyrma which at his time of writing numbered nearly two hundred. He split the genus into three groups: gracilis, tenuis and divers, only one of which - gracilis - was characterized by him.

In the present account we have divided Pseudomyrma into five branches and each of the branches into numerous groups wherever possible. The terms "branch" and "group" were chosen deliberately and are employed in the same sense in which Emery used the term group, to denote a classificatory category which can not be sharply characterized, i.e., where there are too many intergrades to permit the use of such terms as genus or subgenus.

This paper contains the descriptions of a number of new Pseudomyrma which the late W. M. Wheeler had named and labelled as types and cotypes, but whose descriptions have not been published. Professor Brues and Professor Banks have 
advised us to include these descriptions in this paper.

Other undescribed forms were found in the unidentified material of the collection of the Museum of Comparative Zoölogy; the remainder of the newly described forms are material collected by us and for us in Central and South America.

Genus Pseudomyrma (Latreille).

Pseudomyrma is the only American genus of Forel's Promyrmicinæ (Promyrmicini of some writers), which includes the following tribes and genera:

I. Tribe Metaponini Forel

1. Genus Metapone Forel

II. Tribe Pseudomyrmini Forel

1. Genus Sima Roger

2. Genus Pseudomyrma Latreille

Branches. ${ }^{3}$

Branch Ornatinoda. Pl. II, fig. 1, 2; Pl. III, fig. 1, 2, 3.

Characters: The petiole with angular or rounded projections above and behind; or deeply excavated above; or with longitudinal or transverse impressions. This branch corresponds roughly to Emery's group tenuis.

Type: Pseudomyrma tenuis (Fabricius).

Groups: excavata, tenuis, picta-schuppi.

Branch Clavanoda. Pl. II, fig. 3, 4, 5; Pl. III, fig. 15;

$\mathrm{Pl}$. IV, fig. 26-35.

Characters: The petiole is clubshaped, with a long thin peduncle in front, and is not or only weakly marginated at the sides. This branch corresponds to Emery's group gracilis.

Type: Pseudomyrma gracilis (Fabricius).

Groups: lovigata, solisi, mutica, gracilis.

Branch Triangulinoda. Pl. II, fig. 6-12.

Characters: The pedicel from above has approximately the shape of a triangle, usually with rounded corners and convex sides; the peduncle is much shorter than in the preceding branch. The node is margined or submargined in some of the forms.

Type: Pseudomyrma spinicola Emery.

Groups: dolichopsis, sabanica, championi, spinicola, elegans.

${ }^{3}$ An explanation of this term has been given on p. 60 . 
Branch Apedunculata. Pl. II, fig. 13-15.

Characters: The petiole rises from the articulation with the epinotum in a straight line or in a convex line, i.e., the node extends clear to the articulation and the peduncle is not differentiated; the node is usually strongly margined and sometimes the lower face of the petiole in profile is concave.

Type: Pseudomyrma sericea Mayr.

Groups: subtillissima, sericea, acanthobia, elongata, filiformis, fiebrigi-brunnea.

Branch Latinoda. Pl. II, fig. 17-22.

Characters: The peduncle is very short and notably broadened; the node is short and broad, sometimes broader than long; it is usually not margined at the sides.

Type: Pseudomyrma latinoda Mayr.

Groups: triplaridis-maligna, arboris-sanctee, damnosa-latinoda, canescens.

\section{KEY FOR THE IDENTIFICATION OF THE WORKERS of Pseudomyrma ${ }^{4}$}

\section{Branches of Pseudomyrma}

1. The pedicel is ornamented with spines or cones or carinæ on the posterior face, or with longitudinal impression or suture ........Ornatinoda, Pl. II, fig. 1, 2, 3; Pl. III, fig. 1 The petiole is not ornamented.

2. Petiole usually very long, club shaped, not marginate or submarginate. Clavanoda, Pl. II, fig. 4, 5

Petiole not distinctly club shaped

3. Petiole from above triangular in outline; marginate or not marginate; usually with a peduncle. The species which have the petiole triangular but the peduncle very short and broad (canescens, Pl. II, fig. 18), have been included in Latinoda. Triangulinoda, Pl. II, fig. 6-13

Petiole from above not triangular

4. Petiole from above convex at the sides, usually broadest in the posterior third; sometimes subtriangular, but always lacking a differentiated peduncle, i.e., the anterior face

${ }^{4}$ This key can not be used generally for the identification of the females and males, although it is often possible to place the former by means of it. No attempt was made at completeness, because the main purpose of the key is to indicate clearly the position of the newly described forms. 
of the petiole in profile is straight or even convex Apedunculata, Pl. II, fig. 13-15 Pedicel of different shape; with the node transversely oval, or trapezoidal, or globular, or triangular, but always with a very broad and short peduncle.

Latinoda, Pl. II, fig. 17-22

Detailed keys to the groups and species Branch ORNATINODA

1. Pedicel in profile long and low, with the upper border almost horizontal. Pl. III, fig. 3 ..........tenuissima Emery Petiole in profile higher

2. Pedicel in profile with a high rounded node. Pl. III, fig. 1 group excavata

Petiole in profile with a sharp or blunt superior-posterior corner. Pl. III, fig. 2.
A. - Posterior face of the node straight. Pl. II, fig. $2 \ldots$.
B. - Posterior face of the node convex group tenuis group picta-schuppi

The group picta-schuppi is transitional to the branch Latinoda and some of its forms are listed there. We include under Ornatinoda the following additional forms:

1. gebelli-which has a transverse suture on the petiolar node.

2. excissa - the node with a strong semilunar excavation.

3. schuppi var. geraënsis - which has the node excavated on top.

The remaining forms of schuppi we have placed near belti, following Forel.

\section{Group tenuis}

1. tenuis, typical. Length $5 \mathrm{~mm}$. Entirely yellow-ochrous; sides of the head very convex; basal face of the epinotum with a longitudinal impression; node from above long and narrow; prothorax strongly marginate. Maranho, Brazil.

2. var. parcensis. Length $5 \mathrm{~mm}$. Yellowish; mesonotum broader than long (as long as broad in the type); node with rounded angles instead of sharp corners; posterior face of node a little convex. Para, Brazil. 
3. var. pittieri. Length $6 \mathrm{~mm}$. Reddish brown; abdomen brownish. Costa Rica.

4. subsp. nigripes. Color ferruginous red; head black. Brazil, Peru.

5. var. andina var. nov. Length $5 \mathrm{~mm}$. Reddish yellow; sides of the pronotum coarsely sculptured (finely punctate in the type). Peru.

6. var. guatemalensis var. nov. Length $6 \mathrm{~mm}$. Reddish yellow; head brown; prothorax and mesothoracic disc both broader than long; petiolar node without horns or cones, but sharply raised brown margins. Guatemala.

7. var. rufa (redescribed as $P$. rufa by Mann, 1916). Length $6 \mathrm{~mm}$. Color ferruginous; meso- and epinotum infuscated. Pará, Brazil.

\section{Branch Clavanoda}

1. Monocolored forms......................................................2

Bicolored forms.

2. Yellow colored...............group laevigata-solisii (see below) Color brown to black.

A. unicolor (syn of the type and monochroa); black.

B. alfari. Brownish yellow; length $4.1-4.8 \mathrm{~mm}$; peduncle short.

C. duckei. Length 3.5-4 mm.; peduncle short and indistinct; this form is transitional to Apedunculata.

D. nigropilosa. Length $6 \mathrm{~mm}$; t testaceous yellow with black hairs.

3. Larger forms; $11 \mathrm{~mm}$. or larger:

A. gracilis var. major. Yellowish red; head and abdomen black.

B. mutilloides. Black, except the peduncle which is red. Smaller forms; usually under $9 \mathrm{~mm}$............................... 4

4. Thorax not impressed at the mesepinotal suture, which is very faint; length $5.6-6.3 \mathrm{~mm}$; head black, rest of the body reddish brown. The color is however variable salvini

Thorax not impressed

5. Peduncle very short; length $6.5 \mathrm{~mm}$. Pedicel and gaster brown, rest of the body black ............................ godmani

Peduncle longer. 
Gaster light brown with dark brown spots, like freckles.....

Gaster not spotted with brown santschii, sp. nov. (remaining forms).

\section{Group gracilis}

Pl. IV, fig. 26-35

1. Petiolar node in profile with a very steep anterior face. Pl. II, fig. 32; length 9-10 mm.; dark brown subsp. squamifera

Petiolar node of different shape. gracilis group,

Pronotum broader than long; length $8.5 \mathrm{~mm}$.; color variable subsp. agilis

Pronotum as long as broad or longer than broad............... 3

3. Head and thorax smooth and shiny; length $6.4-6.8 \mathrm{~mm}$.; epinotum with a semilunar impression; gaster without pubescence. var. glabiventris

Not with these characters

4. Peduncle relatively short:

A. subsp. maculata. Peduncle shorter than in the type; pilosity more abundant. Pl. III, fig. 34 .

B. gracilis type. Color extremely variable; most of the named forms fall in fact under the definition of the type.

C. subsp. mexicana. More robust than the type; black with the prothorax red. Pl. IV, fig. 29, 33.

D. subsp. carapuna. Smaller than agilis and more pilose than the type. Pl. IV, fig. 27.

Peduncle relatively long, usually with a secondary dilatation at the level of the stigmata:

E. subsp. sericata. Thorax vividly red, head and gaster black. Pl. IV, fig. 26.

F. var. peruviana. Peduncle very long; mesepinotal disc very elongated. Pl. IV, fig. 31 .

G. var. longinoda var. nov. Peduncle very long as in the preceding form; shoulders very overhanging.

(The species alternans and faber are probably nothing more than color varieties of the species gracilis; we have not seen the types.) 


\section{Group leevigata-solisii}

1. loevigata type. Length $8.5 \mathrm{~mm}$.; with fine punctation, body very shiny; color testaceous yellow.

2. subsp. kitscheli. Length $9 \mathrm{~mm}$.; head less convex than in the type; epinotum not narrowed behind.

3. subsp. osura. Length $7.2 \mathrm{~mm}$.; head longer than in the type, longer than broad; base of the epinotum more convex than in the type and in kitscheli; color reddish yellow.

4. subsp. insularis subsp. nov. Smaller than the type and with abundant golden hairs (the pilosity in the type is sparser and black).

5. $P$. solisii. This species is intermediate between Clavanoda and Triangulinoda. We have put it into the latter, because of its short peduncle. It may be considered the extreme border case of this group (lavigata).

6. flavidula. Pl. III, fig. 15. Entirely smooth and shiny; yellow colored; head broader than in pallida; abdomen with a brown spot of variable size. Texas to Brazil.

7. flavidula var. pallida (formerly pallida); very close to the preceding, but the abdomen is not spotted. Florida to Mexico.

8. flavidula var. jaumei. Length $4 \mathrm{~mm}$.; close to the variety pazosi, but with the head shorter and less convex; gaster shiny and black; rest of the body dark red. Cuba.

9. subsp. levivertex. Color reddish yellow; first petiolar node more sharply bordered than in the type; abdomen banded brown. Argentina.

10. subsp. lizeri. Length $6 \mathrm{~mm}$.; abdomen spotted, thorax tinted brown; clypeus not toothed (toothed in levivertex).

\section{Branch Triangulinoda}

Pl. III, fig. 6-10

1. Pedicel in profile less than twice as long as high; peduncle barely indicated by a concave anterior border of the node. Pl. III, fig. 4.

Pedicel in profile more than twice as long as high; peduncle well developed and long. Pl. III, fig. 7 .

2. Thorax without impressed mesepinotal suture; length 6.5 $\mathrm{mm}$; pronotum margined; epinotum and first node reddish, postpetiole and abdomen brown or black. 
Guatemala. (Differs from the related form antiguana by the shorter peduncle.) .............................................stolli Mesepinotal suture impressed 3

3. With a small antero-ventral tooth on the petiole. Pl. III, fig. 8 . group dolichopsis

A. Larger forms, $4.3-5 \mathrm{~mm}$.:

I. dolichopsis. The node in the typical form is very broad and convex on the sides. Colombia.

II. var. curaconsis. Length $4.3-5 \mathrm{~mm}$.; color testaceous; brown in the type. Curaçao.

III. var. implicata. Length $4.3 \mathrm{~mm}$.; head narrower than in the type; erect hairs absent on the femora. Amazonas.

B. Smaller forms: Length 3.6-3.9 mm.; scapes longer than in dolichopsis; reddish yellow or brownish. Guatemala. peperi

With larger antero ventral tooth and with a postero ventral tooth; the two teeth connected by a lamina. Pl. III, fig. 4 . group championi-denticollis

A. denticollis, type and varieties; length 5-7 mm.; unicolored or not.

I. denticollis type. Length 6-7 mm.; reddish; $\mathrm{Pa}$ raguay. Pl. III, fig. 5 .

II. var. infuscata. Length 5-6.2 mm.; head brown, gaster testaceous, sometimes the whole body brown. São Paulo, Brazil.

B. goeldii. Length $3.2-3.5 \mathrm{~mm}$.; pronotum red, rest black. São Paulo.

C. rochai. Length 4-4.7 mm.; head bright red, rest of the body black.

D. championi and subspecies. Pl. III, fig. 4. Length 4.5-5.5 mm.; antero ventral tooth strong and curved backward.

I. championi type. Thorax and petiole red, rest blackish brown; length $4.7 \mathrm{~mm}$.

II. var. haytiana. Same color as the type, but the antennæ are bright yellow; postpetiole and gaster with reddish spots.

III. subsp. haytiana var. affinis. Head black, epinotum with a black streak in the center; pedicel and gaster brown. 
IV. subsp. haytiana var. torquata. Head to postpetiole black, except the pronotum, which is bright red.

V. subsp. haytiana var. paulina. Transitional to subsp. incurrens.

VI. subsp. incurrens. Length 4.6-5.3 mm.; brown as in torquata but the node is three times as long as broad.

4. Unicolored forms. Pl. II, fig. 6........group sabanica-pallens

A. depressa. Length $4.3 \mathrm{~mm}$.; thorax strongly compressed; color brownish black; head as long as broad, with convex sides; smooth and shiny. Colombia.

B. kuenckeli. Pl. II, fig. 10. The node from above forms a short triangle.

I. kuenckeli type. Color reddish testaceous, gaster brownish. Costa Rica.

II. var. bierigi. Length $5 \mathrm{~mm}$.; darker than the type, nearly black; head ferruginous. Panama.

III. var. dichroa. Larger than the type and more robust; head yellowish red, thorax yellow in front, rest of the body brown. Colombia.

IV. var. honduriana. Head reddish brown, thorax dark reddish, gaster brown. Honduras.

(The varieties of $P$. kuenckeli are separated mainly by their color patterns; we have not enough material on hand to determine how real these differences are.)

C. sabanica type. Color dark brown (Pl. II, fig. 6) and the variety saffordi length $3.4-4 \mathrm{~mm}$.; color uniformly brown, lighter than in the type.

D. pallens type. Length 5-6 mm.; color testaceous; pilosity sparse; pubescence moderate. Colombia.

I. var. gibbinoda. Mesonotum very convex (in the type it is straight and forms an acute angle with the base); São Paulo.

II. var. landoldti. Length $6 \mathrm{~mm}$.; reddish yellow; first node much broader than in the type. Colombia.

Bicolored forms.

5. Thorax without mesepinotal constriction 
I. antiguana type. Length $5 \mathrm{~mm}$.; reddish brown, head and gaster slightly darker. Guatemala.

II. var. brunneipes var. nov. Length $6 \mathrm{~mm}$.; sides of the thorax and petiole bright yellow contrasting sharply with the dark brown legs. Guatemala.

Thorax with a pronounced mesepinotal constriction..........6

6. Smaller forms. Pl. III, fig. 7. ................ group spinicola

A. edvardi type. Color black and the variety caccilice. Black as the type; length $2.9-3 \mathrm{~mm}$. Differs from the type by the straight posterior edge of the head (concave in the type).

B. ejecta type. Length $1 \frac{1}{2}$ lines. Color rufo-testaceous, gaster black, and the variety peruviana. Same size as the type; head to mesothorax testaceous, rest of the body rich castaneous.

C. distincta type. Close to ejecta but with the head black, and the variety pulchella. This variety is listed under the larger forms below.

D. mutica. Length $5.2-6.2 \mathrm{~mm}$.; rusty red, head and gaster brown; peduncle nearly obsolete. This form is transitional to Apedunculata. It is distinguished by having the posterior face of the first node vertical as in denticollis.

E. kurokii. Length $4.6 \mathrm{~mm}$.; reddish brown, gaster brown, and the variety rufiventris. Length $6.1 \mathrm{~mm}$. (only the female known).

F. solisii type. Length $4 \mathrm{~mm}$. Near mutica but with the head more convex; petiolar node evenly rounded and the variety belgranoi. Length $5 \mathrm{~mm}$; differs from the type in the shape of the petiole.

The species mutica and solisii are transitional to Clavanoda and are listed again under that branch.

G. spinicola. Node rounded, without antero-ventral tooth. Pl. III, fig. 7.

I. spinicola type. Length 4-5.5 mm.; testaceous, gaster darker.

II. var. convarians. Length $3.6 \mathrm{~mm}$; head shorter than in the type.

III. var. gaigei. Length $4.5-5.2 \mathrm{~mm}$.; color vividly red. 
IV. var. atrox. Length 4-4.7 $\mathrm{mm}$; head almost as broad as long.

V. var. infernalis. Differs from the type by lack of margination, from convarians by larger size, from gaigei by the narrow postpetiole and from atrox by the nonenotched clypeal lobe.

VI. var. scelerosa. Very near to infernalis but with the mesonotal disc more elevated (low in infernalis).

Larger forms. Pl. II, fig. 7. group elegans

A. auripes. Length $8 \mathrm{~mm}$; color blackish brown with yellow legs, contrasting sharply.

B. distincta var. pulchella (see also under spinicola). Head and abdomen black, thorax and pedicel ferruginous red; length $8 \mathrm{~mm}$.

C. elegans type. Head and abdomen black, thorax and pedicel ferruginous red. Length three lines (about $8 \mathrm{~mm}$.), and the variety breviceps. Head shorter than in the type; petiole narrower with less margination; petiole and thorax deep red with brown spots. (The differences given in Forel's description warrant raising the variety to the rank of a species. We have not seen the type of the variety.)

\section{Branch Apedunculata}

1. Petiole in profile less than twice as long as high. Pl. III, fig. 10 .

2

Petiole in profile more than twice as long as high. Pl. III, fig. 18.

2. Very slender forms with long and narrow head:

A. subtillissima type. Length 3-3.5 mm.; color testaceous. Costa Rica. (The variety tenuissima has been raised to species rank and listed under Ornatinoda.)

B. voytowskii. Length $2.2 \mathrm{~mm}$.; occiput transparent; prothorax yellow, rest of the body brown, Peru, and the variety costariensis. Length $4.2 \mathrm{~mm}$.; head reddish brown; opaque (shiny in the type). Costa Rica.

More robust forms. 3

3. Petiole with backwardly directed antero-ventral tooth. Pl. III, fig. 10.

A. wessoni. Length $3.5-4 \mathrm{~mm}$.; uniformly yellow; pedi- 
cel and gaster shiny, rest of the body opaque. Peru. Pl. III, fig. 10. The variety tuberculata. Epinotum with small tubercles at the junction of the base and the declivity. Pl. III, fig. 12. The type lacks the tubercles.

B. allidora. Length 3-3.5 mm.; intermediate between sericea and acanthobia in the shape of the petiole; differs from the former by its brown color, from the latter by the absence of erect hairs. Panama.

C. weberi. Length 3.8-4 mm.; head reddish brown, weakly bicolored on the rest of the body; this species is easily recognized by the peculiar shape of its petiole in profile. Pl. III, fig. 16. It is transitional to decipiens.

Petiole with a triangular lamella in place of the antero ventral tooth. (Some forms have a tooth, i.e., sericea fortis.) Pl. III, fig. 17 .

4. With an antero ventral and a posterior tooth, the two teeth connected by a serrated lamina. Pl. III, fig. 19.......... 5

Without a posterior tooth, but the lamella is present. Pl. III, fig. 20. Color brown.

5. All forms belonging here are black or very dark brown and all have a silky shine.

A. sericea type. Length $4.5-5.5 \mathrm{~mm}$.; Colombia. Pl. III, fig. 11.

B. var. altinoda. Length $4 \mathrm{~mm}$; petiole higher than in the type, two-thirds as high as the thorax; differs from the type in color. Brazil.

C. var. cordice. Smaller than the type; clypeal lobe triangular. Peru.

D. var. fortis. Length $6 \mathrm{~mm}$.; base of the epinotum longer than the declivity. Mexico.

E. var. huberi. Length $4.5 \mathrm{~mm}$; abdomen grayish, otherwise as in rubiginosa.

F. var. ita. Length $4.5 \mathrm{~mm}$.; the first node has a very convex anterior face, the second node is smaller than in the type. Costa Rica.

G. var. longior. Length 5.5-6 mm.; clypeal lobe triangular; color as in fortis. Brazil.

H. rubiginosa. Head black, front of pronotum deep 
brown, first node banded with brown, abdomen black, rest of the body rusty red. Brazil.

I. var. vineni. As in cordiæ, but with larger eyes; base of the epinotum very convex; length $3.5-4.5 \mathrm{~mm}$. Brazil.

K. var. acaciorum. Length $3.5-3.8 \mathrm{~mm}$; chocolate brown; clypeal lobe rounded; coloration distinctive. Panama.

L. var. lisa. Near acaciorum, but with the sides of the thorax smooth (punctate in acaciorum); color scheme more vivid.

6. Light brown forms; acanthobia and varieties.

A. acanthobia type. Reddish yellow with brown spots on the abdomen; pronotum not marginate. Paraguay. Pl. III, fig. 13.

B. var. capperi. Differs from the type by having the first node margined. Jamaica.

C. var. cocoe. Smaller than the type; length 5.5-6 mm.; sculpture coarser. Argentina.

D. var. fuscata. Darker colored than the type. Paraguay.

E. var. panamensis. Length $4 \mathrm{~mm}$.; petiole shorter than in the type.

F. var. virgo Sant. Length $3.5 \mathrm{~mm}$.; yellowish, gaster not spotted. Brazil.

G. subsp. deliculata. Length 3-3.5 mm.; pedicel very narrow compared with the width of the thorax; brownish yellow with brown spots on the abdomen. Jamaica. Pl. III, fig. 13.

H. subsp. deliculata var. vittata. Length $3.4-4 \mathrm{~mm}$; with brown bands on the second and third gastric segments. Brazil.

I. subsp. deliculata var. limai var. nov. Length 2-3 $\mathrm{mm}$.; very shiny; occiput transparent; abdominal spots very small. Peru.

Dark brown to black forms:

A. elongata type. Length 3-4.5 mm.; head narrowed behind; color dark brown to black. Colombia. Pl. III, fig. 12.

B. var. tandem. Head shorter than in the type; petiole thinner. Costa Rica. 
C. var. subatra. Length 4-4.5 mm.; head shorter than in the type; epinotal base shorter; sculpture coarser than in the other varieties. Haiti.

7. Color dark, brown to black ............. group fiebrigi-brunnea.

A. fiebrigi. Length 3.7-4 mm.; blackish brown to black; pronotum bluntly margined. Paraguay.

B. culmicola. Length $3 \mathrm{~mm}$; reddish brown, abdomen brown; close to the type but with thicker antennæ and a smaller petiole. Trinidad.

C. holmgreni. Length $4.2 \mathrm{~mm}$.; testaceous brownish yellow, gaster brown. Peru.

D. euryblemma. Length $5 \mathrm{~mm}$.; pronotum not marginate; reddish brown. Costa Rica.

E. peltata. Length $6.8 \mathrm{~mm}$.; ferruginous red; peduncle long. This form is transitional to Clavanoda.

F. brunnea. Length $2.5-3 \mathrm{~mm}$.; head with nearly parallel sides; color dark brown, gaster blackish.

G. brunnea var. nigrita var. nov. Head opaque (shiny in the type); black with white mandibles.

$\mathrm{H}$. colei $\mathrm{sp}$. nov. Length $4.5 \mathrm{~mm}$.; nearly naked; head and prothorax reddish brown, gaster black. Peru.

I. colei var. vistana var. nov. Head bright reddish, occiput dark brown, petiole and gaster dark brown. Peru.

Color lighter, light brown or yellow. 8

8. Petiole in profile very long

filiformis and varieties

A. filiformis type. Length $4-5.5 \mathrm{~mm}$; head yellowish red, gaster brown. Guatemala. Pl. III, fig. 18.

B. var. longiceps. Larger than the type; head much longer. Colombia.

Petiole in profile shorter

9. Petiole in profile with a small antero ventral tooth

decipiens

A. decipiens type. Length 5-7 mm.; node transitional to salvini and gracilis; reddish yellow; base of the abdomen banded brown.

B. var. longior. Length $6.4-6.7 \mathrm{~mm}$.; head longer than in the type; first node higher.

Petiole without a tooth below. Pl. III, fig. 14...nigrocincta

A. nigrocincta type. Length 4-4.5 mm.; yellow, with fuscous spots on the abdomen. Costa Rica. 
B. var. bicincta. Head rectangular (narrowed behind in the type); base of the petiole and gaster brown.

Branch Latinoda

1. Color bright yellow, last gastric segment brownish; petiole stout with a short peduncle and a round node, rising sharply from it. Trinidad. Length $6 \mathrm{~mm}$............icterica

Color darker

2. Petiole below without or with a very small antero ventral tooth. Pl. III, fig. 23

Petiole with a large tooth and usually with a broad lamella except in maligna-cholerica, which lacks the tooth. Pl. III, fig. 20

3. Head oval, not longer than broad. Pl. III, fig. 23 .......belti

A. belti type. Length 5-6 mm.; petiole with a small tooth; thorax narrowly marginated. Costa Rica.

B. var. obnubila. Length $6-6.8 \mathrm{~mm}$.; black; more robust than the type; peduncle longer and broader. Costa Rica.

C. subsp. fulvescens. Color reddish testaceous; gaster brown; thorax flatter than in the type.

D. subsp. venifica. Length 4-4.5 mm.; deep brown; petiole and gaster sometimes lighter; very hairy. Mexico.

E. subsp. bequarti. Length 5-6 mm.; head a little longer with convex sides; prothorax not marginate; differs from the other varieties by its uniformly brown color.

Head a little longer than broad

4. Head narrowed behind; color uniformly dark brown; node almost as long as broad; petiole without a ventral tooth; very hairy caroli

Head not narrowed behind 5

5. Clypeus in front with two blunt teeth, as in the genus Sima; length $6.5 \mathrm{~mm}$.; petiole as broad behind as long; color brownish yellow. Amazonas. simoides

Clypeus not with blunt teeth

6. Group canescens. Pl. III, fig. 22.

A. canescens. Length 5.5-6.5 mm.; head longer than broad, with nearly parallel sides; antennæ surpassing the head. Mexico.

B. bradleyi. Length $5.5 \mathrm{~mm}$.; uniformly light brown; 
prothorax not marginated; node subglobular; petiole with a small tooth. Peru.

7. Petiole with a vertical posterior face and a lamina below, ending in front in a triangular tooth. Pl. III, fig. 21.

A. picta type. Length $5.5 \mathrm{~mm}$.; pronotum marginate; node from above trapezoidal and marginate, the margins ending behind in blunt teeth (transitional to Ornatinoda). Ground color red with a complicated black pattern superimposed. Brazil.

B. var. humboldi. Without postero superior teeth on the first node.

Petiole shaped differently 8

8. Petiole with a relatively long peduncle and a strong tooth, sometimes continued backward in a crenulated lamellæ. Pl. III, fig. 19. group triplaridis-maligna Petiole without peduncle, lamella not crenulated. Pl. III, fig. 20. group arboris-sanctoe

\section{GROUP TRIPLARIDIS-MALIGNA}

A. ulei. Length 4-5 mm.; mandibles angular near the base; head rectangular with nearly parallel sides; color as in caroli. Amazonas.

B. maligna.

I. maligna type. Length 4-4.6 mm.; thorax submarginate; petiole from above globular; petiolar node abrupt behind; color deep castaneous. British Guiana.

II. var. cholerica. Length 3-3.5 mm.; lighter colored than the type and weakly bicolored; without a ventral tooth on the petiole. British Guiana.

III. var. crucians. Length 3-3.5 mm.; very dark brown, sometimes black. British Guiana.

C. triplaridis. Head long and narrow; mandibles not lighter than the rest of the body as is almost invariably the case in Pseudomyrma.

I. triplaridis type. Length $4.5-4.8 \mathrm{~mm}$; petiolar node from above subhexagonal. Amazonas.

II. subsp. biolleyi. Length 4.8-5.2 mm.; eyes smaller than in the type; node from above globular; head reddish brown, gaster brown, first gastric segment and rest of the body reddish. British Guiana. 
III. subsp. boxi. Length $4 \mathrm{~mm}$; mandibles not darker than the head, color brownish yellow; sculpture stronger than in the other forms. British Guiana.

IV. subsp. trigona. Length 4-4.8 mm.; mesonotal disc angular as in the type; epinotum ovoid and convex. Color uniformly red. British Guiana.

\section{GROUP ARBORIS-SANCT $A$}

A. schuppi and var. Antennæ beaded; frontal carinæ indistinct; close to belti in the shape of the head; length 4.5-5 $\mathrm{mm}$. (the variety geranensis has the first node excavated above and is therefore transitional to Ornatinoda, where we have listed it).

B. oki. Length $3.5 \mathrm{~mm}$.; like a small belti fulvescens; the clypeus without lobe; pronotum marginate; node as in belti but without a peduncle.

C. latinoda. Pl. III, fig. 19.

I. latinoda type. Length $4 \mathrm{~mm}$; rufo testaceous; petiole very short. Brazil.

II. var. endophyta. Length 4.1-5.3 mm.; more robust than the type; color reddish yellow. Brazil.

III. var. nigrescens. Length 4.4-4.8 mm.; petiole and thorax black, rest of the body reddish yellow; darker than the type. Brazil.

IV. var. opacior. Length $4.3 \mathrm{~mm}$.; pronotum gently sloping, not abrupt as in nigrescens; color uniformly brownish yellow. Cuba.

V. subsp. tachigalice. Head longer than in the type, with parallel sides, clypeus with a rectangular lobe. Brazil.

VI. var. coronata. Length 5.5-6 mm.; head testaceous with a brown spot on the occiput; rest of the body dark brown. British Guiana.

D. dendroica. Close to arboris-sanctce.

I. dendroica type. Length $6.5 \mathrm{~mm}$.; robust; pronotum marginate; color deep brown. Brazil.

II. var. emarginata. Head broader than in the type. Brazil.

E. arboris-sanctæ. Pl. III, fig. 20.

I. arboris-sanctoe type. Length $5.6 \mathrm{~mm}$; testaceous, head darker; first node very transverse. Bolivia. 
II. var. cordobensis. Length $6-6.5 \mathrm{~mm}$; head not concave behind as in the type; color reddish yellow. Argentina.

III. subsp. symbiotica. Length 4.4-4.7 mm.; color reddish yellow, middle of the gaster brown.

IV. subsp. symbiotica var. lowensohni. Length 5.5-5.7 $\mathrm{mm}$.; color reddish brown. Panama.

V. var. ecuadoriana var. nov. Length $5.5 \mathrm{~mm}$.; with a brown occipital spot; postpetiole more transverse than in the type; color reddish brown, first three abdominal segments banded brown. Ecuador.

Pseudomyrma acanthobia, subsp. deliculata var. limai var. nov. Pl. IV, fig. 24.

Worker.

Length 2-3 $\mathrm{mm}$. Close to the subspecies deliculata from which it differs by the following characters. The whole body, except the pedicel, very shiny (the subspecies is sublucid). Smaller and slenderer. The whole occiput is transparent showing the outlines of the brain (the type is a little transparent on the occiput). The scapes are shorter and fail to reach the middle of the eyes. The petiole is even more slender than in deliculat $a$ and is finely punctate and subopaque. The abdominal spots are barely visible, or absent in some specimens, while in deliculata they are dark brown and large. Described from several workers taken from an unspecified tree.

Type locality: Lima, Peru.

Holotype No. 75, Haskins Collection, located in the Biological Laboratories, Harvard University, Cambridge, Massachusetts.

Worker.

Pseudomyrma allidora sp. nov.

Length $3-3.5 \mathrm{~mm}$. The new species is intermediate between $P$. acanthobia and $P$. sericea in the shape of the pedicel. It differs from $P$. sericea by its lighter color and from $P$. acanthobia by the presence of erect hairs, a much longer head, coarser sculpturing on head and thorax, absence of brown spots on the abdomen, etc.

Head, without mandibles, about 11/2 times as long as broad with nearly straight sides and weakly concave posterior border. 
The eyes are flat and large, occupying more than half the sides of the head. The mandibles are yellow, with two large apical and three small basal teeth, all black; heavily striated. The clypeal lobe is rectangular and not excised. The scapes fail to reach the middle of the head. The head is evenly and densely punctate, opaque, devoid of erect hairs, but with fine white pubescence on the vertex. The prothorax is longer than broad, and distinctly margined on the sides; the mesonotal disc has an acute angle in front, behind it is semicircular. The epinotal base is longer than broad, broadest in front, narrowed behind, where it meets the epinotal declivity. The petiole is subtriangular from above, with convex sides and rounded posterior edge; the postpetiole is as long as broad and nodiform. The thorax in profile is slightly convex above with a strong depression at the mesepinotal suture. The base and the declivity of the epinotum meet at a rather sharp angle. The node in profile is shaped as in $P$. sericea; but has a pronouncedly backward curved anterio-ventral tooth (the tooth is triangular in $P$. sericea).

The pilosity is sparse on the thorax, pedicel and abdomen, absent elsewhere. The pubescence is also sparse, except on the postpetiole and gaster, where it is relatively abundant, white and silky. The color is brownish-yellow, with the prothorax and petiole a little lighter; the head sometimes a little blackish. Mandibles and tarsi clear yellow.

Habitat: Ancon, Canal Zone (Type locality). On Cordia allidora. Miraflores, Canal Zone. On Triplaris cumingiana. The specimens from Miraflores have the gaster subopaque (shiny in the specimens from the type locality).

Cotype 20533, Harvard Collection, Mus. Comp. Zoölogy (21 specimens).

Worker.

Pseudomyrma antiguana sp. nov.

Length $5 \mathrm{~mm}$. The whole body reddish brown, with the head and gaster dark reddish brown. Head and thorax densely and coarsely punctate, the rest of the body finely punctate and opaque throughout. The new form belongs to the branch Triangulinoda and is close to the bicolored species spinicola, which has a long peduncle with the faintest indication of an anteroventral tooth, placed very close to the articulation with the epinotum. 
The new form is sufficiently different from spinicola to be listed as a separate species. The structure of the thorax of the new species is in marked contrast to that of $P$. spinicola; it is evenly convex in profile, without any depression at the mesepinotal suture. From above this suture is very faint, nearly obsolete. The mandibles are almost as dark as the rest of the head, a feature which distinguishes $P$. triplaridis, which however belongs to another branch. The mandibles are curiously flattened, as if they had been artificially crushed, and strongly rugose, each ruga leading to a tooth. The frontal carinæ are very close together.

Type locality: Antigua, Guatemala (Wheeler coll.).

Holotype No. 84, Haskins Collection; two paratypes.

Pseudomyrma antiguana var. brunnipes var. nov.

Worker.

Length $6 \mathrm{~mm}$. With the general features of the type, that is the flattened mandibles and the very faint mesepinotal suture. It differs from the type by its shorter and more robust petiole, which has a shorter peduncle. The frontal carinæ are longer and farther apart than in the type. The color pattern is very striking. The whole body, including the mandibles and legs, dark reddish brown and contrasting very sharply with the thorax and petiole, both of which are bright yellow on the sides and brownish yellow dorsally. The petiolar node is almost as dark as the postpetiole and gaster. The second abdominal segment has the anterior half golden yellow, the posterior half dark brown.

Type locality: San Lucas, Toliman, Guatemala (Wheeler coll.).

Holotype No. 85, Haskins Collection.

Pseudomyrma arboris-sanctæ var. ecuadoriana, var. nov.

Worker.

Described from numerous workers collected for us in Ecuador. Length $5.5 \mathrm{~mm}$. Head $1 \mathrm{I} / 4$ longer than broad, with very convex sides and straight posterior border. Mandibles very strongly striate, with two large apical and several small blunt basal teeth. The clypeal lobe is very short and rectangular. The scapes are much thickened apically and reach the middle of the eyes. Head densely foveolate, not punctate; on the occiput 
with a brown spot around the ocelli. Prothorax as long as broad, not marginated at the sides. Mesothorax with an almost circular disc which is a little elevated, separated from the base of the epinotum by a wide depression; the latter is longer than broad, broadest at the level of the stigmata, and very convex transversely. The petiole is shaped as in the type; the postpetiole is more transverse. The posterior edge of the first, second and third segments are brown, the tip of the gaster and the gaster below are brown. The rest of the body is reddish brown, except for the brown spot on the occiput.

Type locality: Ecuador.

The new form differs from the type arboris-sanctoe in coloration. The type has the anterior edge of the head and the prothorax light yellow, the mesonotal disc dark brown, and the occipital spot very small. The pilosity and pubescence is much more developed in the new variety, the eyes are larger and more convex. From the other forms of arboris-sanctee the new variety differs by the characters given in the key.

Described from 5 workers in the Collection of the Museum of Comparative Zoölogy, labelled Cotype 26809.

Pseudomyrma belti subsp. bequærti subsp. nov.

Worker.

Length 5-6 mm. Head a little longer than broad with very convex sides and straight posterior edge. Mandibles very shiny; clypeus with a short broad rectangular lobe in front; scapes reaching beyond the middle of the eyes. Eyes very large and convex, occupying more than half the sides of the head. Head coarsely and evenly punctate, with very sparse erect hairs.

Prothorax longer than broad, not marginated on the sides. Mesothoracic disc triangular with well rounded angles. Epinotum about twice as long as broad. In profile the prothorax is slightly convex above, the epinotal base nearly flat; the base rounds into the declivity without an angle.

Petiole from above $1 \frac{1}{2}$ times as long as broad, the node broader behind than in front, the posterior edge rounded. Postpetiole about as broad as long, twice as broad as the petiole. In profile the petiole is $1 \mathrm{t} / 2$ times as long as high, with a very short peduncle; the node evenly rounded with the posterior face a little more abrupt.

Erect hairs sparse on thorax, pedicel and abdomen. Pubes- 
cence long and adpressed, on the tibiæ short and fine. Head to pedicel opaque, gaster subopaque. Color uniformly brownish yellow.

Type locality: Puerto Castillio, Honduras (Bequaert). In Acacia.

The new subspecies is easily distinguished from the type as well as from the other varieties and subspecies by its color. It is closest to the subspecies fulvescens Emery, which is reddishtestaceous with a darker abdomen. The pedicel from above in fulvescens is nearly triangular, with convex sides and blunt margin.

Cotype 23139, Harvard Collection, 8 specimens.

Pseudomyrma belti subsp. venifica subsp. nov.

Worker.

Length 4-4.5 mm. Head shaped as in the type. Mandibles faintly striated. Clypeus with a much narrower but rectangular lobe; front and clypeus with abundant pilosity. Prothorax about as long as broad, not marginate at the sides. Mesonotal disc transversely oval; epinotum nearly twice as long as broad, broadest at the level of the stigmata. The node from above shaped as in $P$. decipiens (Pl. II, fig. 13), not marginate at the sides. Postpetiole broader than long, more than twice as broad as the petiole. Abdomen very slender. Thorax strongly constricted between the meso- and epinotum, seen in profile. The epinotum is very convex, the base evenly rounded into the declivity, not forming an angle. The petiole in profile as in P. belti bequarti.

Color deep brown, the prothorax and petiole and sometimes the gaster lighter brown.

Type locality: Manzanillo, Colima, Mexico. (Townsend).

Female.

Length $5 \mathrm{~mm}$. The female is very distinctly bicolored with a reddish brown ground color; the prothorax, mesothorax (except the disc) and petiole very light brown to yellow.

This form is easily recognized by its extraordinarily long pubescence, especially on the pedicel, gaster and legs, which gives this ant a shaggy appearance. It is a transition form but nearer to belti than to $P$. decipiens.

Described from 20 specimens, labelled Cotype 20538, in the Collection of the Museum of Comparative Zoölogy. 
Pseudomyrma bradleyi sp. nov.

Worker.

Length 4.5-5 mm. Color uniformly light brown, or yellow brown except the mandibles, front of the head, tarsi and articulations of the legs, which are yellow. Differs from P. latinoda var. coronata by having the sides of the head nearly straight, so that the head seen from above is nearly a perfect rectangle; the antennæ are brownish, not clear yellow as in coronata. The prothorax is much narrower than long in the median line; the epinotum is almost flat transversely, broadest just behind the mesepinotal impression. The prothorax is not marginated. The node of the petiole is subglobular, a little narrower in front. The postpetiole is shaped as in coronata. In profile the pro- and meso-notum together form a convex line, which is interrupted by the promesonotal suture. The base of the epinotum is straight and forms a blunt angle with the declivity. The petiole in profile has a very short peduncle, almost "apedunculate," with convex anterior and posterior faces, the latter more abrupt. There is no trace of margin on the node.

Pilosity practically absent on the vertex, thorax and petiole, sparse on the postpetiole, gaster and legs. The pubescence is moderately abundant, adpressed, fine and white. The whole body with very fine punctation, coarser on the head, and subopaque.

This form is close to latinoda but differs from it in several major characters, which justifies listing it as a separate species.

Type locality: Perene, Peru. (Bradley).

Cotype 22864, Harvard Collection, 6 specimens.

Pseudomyrma brunnea var. nigrita var. nov.

Worker.

Similar to the type in size and structure and with the epinotal declivity much longer than the base (as in the type). It differs from $P$. brunnea by the much coarser sculpturing on the head and thorax, which renders it opaque (shiny in the type); the stouter body; the coloration which is black in the new variety, except for the mandibles, which are white and contrast strikingly with the rest of the head (mandibles yellow in the type). The head is long and narrow in the type while in the variety it is almost as broad as long. 
Type locality: Mirador, Mexico.

Described from 3 workers, labelled Cotype 26810, in the Collection of the Museum of Comparative Zoölogy. The Haskins Collection has 6 workers from Camaron, Mexico.

Pseudomyrma colei sp. nov.

Worker.

Length $4.5 \mathrm{~mm}$. Head $1 \mathrm{I} / 4$ times as long as broad, broader in front, with very round occipital corners and straight posterior edge. Mandibles strongly striated, with two apical, but no basal teeth. The clypeus with a very short and narrow anterior lobe which is weakly excised in the middle. The eyes are about half as large as the sides of the head and are flat. The scapes reach the middle of the head. The head is finely punctate and shiny. Prothorax broader than its length in the midline, not margined, finely punctate. The mesothoracic disc is transverse. The base of the epinotum is twice as long as broad, broadest at the level of the stigmata, a little narrower at the junction with the epinotal declivity. The petiole from above is shaped as in P. decipiens. The postpetiole is $11 / 2$ times as broad as the petiole, broader than long, and nodiform. The thorax in profile is slender, a little convex above, strongly impressed at the mesepinotal suture. The base and declivity of the epinotum form a blunt angle. The petiole in profile is distinctive and separates this form from all other related species. It is twice as long as high and has four distinct faces; the slightly concave anterior face rises from a short peduncle; the superior face is convex and higher behind than in front; the posterior face is convex and abrupt and ends in a sort of posterior peduncle. Below, the petiole has a small blunt tooth, shaped as in $P$. elongata.

The new species is nearly naked: the pilosity is restricted to the mouth, and the extremely fine pubescence to the funiculi and the tarsi. Color: tibiæ antennæ, tarsi and tip of the gaster yellow. Head and prothorax reddish brown, the rest of the body almost black.

Type locality: Bella Vista, Peru (800 m. sea level). Taken from an unknown tree.

Holotype No. 71, Haskins Collection. 
Pseudomyrma colei var. vistana var. nov.

Worker.

Described from a large number of workers, taken from the leaves of an unknown tree. The new form is almost identical with the type in structure, but differs markedly from it in coloration. The mandibles are very pale yellow, with black teeth. The head and antennæ are bright reddish-yellow, but all of the occiput, behind the eyes, is dark brown. The prothorax is yellow with a large brown spot in the middle; the mesonotum and epinotum are black; the pedicel and abdomen dark brown. The middle and hind coxæ and the middle swollen parts of the femora are reddish brown, the rest of the legs is yellow. The ventral part of the epinotum, pedicel and gaster are reddish yellow. The gaster is very smooth and shiny.

Type locality: Bella Vista, Peru.

Described from 6 workers labelled Cotype No. 72, Haskins Collection. One pin has been deposited in the Museum of Comparative Zoölogy, and was labelled Cotype 26811.

Worker.

Pseudomyrma crenulata sp. nov.

Described from specimens labelled erroneously P. kuenckeli in the Harvard Collection.

Length $5-5.5 \mathrm{~mm}$. Head as broad as long, markedly narrowed in front, with convex sides, well rounded posterior corners and straight occipital edge. The eyes are less than half the length of the sides of the head and very convex. Mandibles powerful and coarsely rugose; clypeal lobe very short, broad and rectangular. Antennal scapes reaching beyond the middle of the eyes but do not attain the occipital border. The whole head finely shagreened-punctate and shiny. Prothorax as broad as long in the midline, sharply bordered with the border crenulate (this is the first Pseudomyrma we have seen which has this character). Mesothoracic disc semicircular in front, concave behind; weakly elevated. Epinotal declivity broadest behind; petiole node trapezoidal, twice as broad as long. Postpetiole broader than long, with blunt corners at the sides. Thorax in profile weakly convex above, the epinotal declivity almost vertical. Petiole in profile similar to that of $P$. maligna, but shorter, with a nearly vertical posterior face and weakly crenulated lamina. Gaster very stout. 
The color is uniformly testaceous yellow, infuscated at the vertex and middle femora. The pilosity is abundant, long and erect. The pubescence is long and untidy giving the ant an unkempt appearance.

Type locality: Guernavaca, Mexico.

Holotype No. 76, Haskins Collection; 3 paratypes.

The new species is related to the triplaridis-maligna group but differs from the related species by a series of unusual characters such as the broad node, the head narrowed in front, the crenulated epinotal margin.

\section{GROUP gracilis.}

Of all the descriptions of forms which undoubtedly belong to the gracilis group 15 are good enough to permit the student to recognize the form, although even here some descriptions are not adequate to decide between two or more. The gracilis group shows in miniature the weaknesses of the whole genus Pseudomyrma, namely a planless accumulation of bad descriptions. Nobody really knows how many forms of gracilis have actually been described, because many of F. Smith's undecipherable descriptions may refer to gracilis.

The confusion arose because an entirely useless character (as far as this species is concerned) has been chosen as the chief diagnostic character, that is the color pattern. A casual collector, who picks up a specimen here and there and does not pay much attention to the structural features, will come to the conclusion that gracilis is a large group containing many dozens of good species; the color patterns are very striking indeed. They are however practically worthless, because even individuals from the same nest show marked differences. Several of the forms which are now recognized as subspecies or varieties in good standing exhibit the larger part of the variation range of the type series. This is shown in the diagram (Pl. IV, Fig. 26-30).

All forms of gracilis have at least part of the body black or dark brown; on the other hand there is no form which is completely black. The original type gracilis (Fabr.) has only the mandibles and the petiolar peduncle light colored; the other extreme is found in some specimens from the Amazon Valley, which have only the head black and the rest of the body yellow.

The fallacy of basing species, subspecies or varieties of gra- 
cilis on color alone, has been recognized early. Emery (1890) after studying a large series came to the conclusion that $P$. $g r a-$ cilis (Fabr.), P. bicolor (Guérin), and the variety dimidiata Roger were identical. Emery proposed $P$. bicolor as the type of the species. Forel later made $P$. termitaria $\mathrm{Sm}$. a synonym of the type. It differs from the type by its smaller stature, but falls without question into the size range of the type series.

But even if other characters had been chosen to separate the forms of gracilis, its classification would still be very difficult. We have attempted to do this in our key, but have not been very successful. For instance $P$. maculata Smith (now subsp. maculata) is said to differ from the type by its shorter peduncle. We have studied a large series of specimens covering the whole area from Texas to Southern Brazil and Peru; all we can say is that the South American forms usually have longer and more slender pedicels, but even the type series includes forms with long and short peduncles, and intermediate forms are very common.

Every other character which might be chosen to effect a separation shows similar gradations. The elevation of the mesonotal disc, used by some writers shows all grades of development not only in the type series but in the series of mexicana, agilis and sericea as well.

The only reason we retain most of the names and even add to them is that the names sometimes are associated with the extreme development of some given character, and that certain color and structure patterns are characteristic of given regions.

Pseudomyrma gracilis var. peruviana var. nov.

Worker.

Length $8.5-9 \mathrm{~mm}$. Identical with the variety longinoda from the same general locality. It differs from the latter by coloration, having the mandibles, clypeus, pedicel and gaster pale yellow; funiculi, coxæ and femora reddish brown to brownish yellow; rest of the legs and the scapes testaceous; head and thorax black. We have seen a similar color pattern in some specimens of the subsp. agilis, from which the new variety differs by the very pronounced shoulders. From the variety longinoda, its closest relative, it differs by its very abundant, long erect hairs on the occiput and thorax, and the opaque gaster (shiny in longinoda).

Type locality: Lima, Peru. 
It is not unlikely that further collections in Peru will unearth numerous intergrades between the two new varieties.

Holotype No. 89, Haskins Collection.

Pseudomyrma gracilis var. longinoda var. nov.

Worker.

Length $8-8.5 \mathrm{~mm}$. Color black, except for the mandibles, clypeus, peduncle of the petiole, which are yellow or reddish yellow, antennæ, tibiæ and tarsi brownish red. The coloration conforms to the description of the type $P$. gracilis (Faber, not Emery). Head opaque, rest of the body subopaque (as in $P$. bicolor). Postpetiole much longer than broad, piriform, as in dimitiata (more nodiform in bicolor, sericata mexicana). The peduncle is very long and has a secondary swelling at the location of the spiracles (this feature is much less developed in all other forms). Pronotum powerfully marginate with large overhanging shoulders, much more pronounced than in agilis. The clypeal lobe is very broad and nearly rectangular, as in some forms of the type series.

Type locality: Bella Vista, Peru. From fallen leaves.

We name this new form because it shows two characters in extreme development: the length of the petiolar peduncle and the margination of the thorax. It is nearest to agilis, from which it differs by a very much higher mesonotal disc, as well as by accentuation of some of the distinctive characters of agilis.

Cotype No. 90, Haskins Collection; one pin has been deposited in the Museum of Comparative Zoölogy, where it has been labelled Cotype 26812.

Pseudomyrma kuenckeli var. hondurana var. nov.

Worker.

Differing from the type in color pattern. Head reddish brown, darker than in the type; thorax dark reddish; gaster brown; front of the head and mandibles yellow.

The varieties of the species kuenckeli are separated mainly by their color pattern. We have not enough material on hand to make any positive statements as to whether color differences can be regarded as a good character for the separation of named varieties.

Type locality: Honduras (Bates coll.). Other specimens of this variety in the Haskins Collection are from Guatemala. 
Described from 6 workers in the Museum of Comparative Zoölogy, labelled Cotype 26814.

Pseudomyrma lævigata subsp. insularis subsp. nov.

Worker.

Length $6.5-7 \mathrm{~mm}$. Differs from the type by smaller size (type $8.5 \mathrm{~mm}$.); character of the pilosity (long and black in the type, more sparse, shorter, and of golden color in the new subspecies); the shape of the prothorax (broad and flat above in the type, narrow and slightly curved in insularis); the coloration (bright yellow in the type, reddish yellow in the subspecies). The differences between the new subspecies and the remaining forms of $P$. loevigata are given in the key.

Type locality: Barro Colorado Island, Panama.

Holotype No. 81, Haskins Collection.

Pseudomyrma latinoda var. coronata var. nov.

Worker.

Length 5.5-6 mm. Cotype 20542, Harvard Collection, 19 specimens. Tarsi and head testaceous-yellow. On the vertex a brown spot of variable shape and size; rest of the body dark brown. Head a little longer than broad, with very convex sides and slightly concave posterior border. The eyes are in the middle, very flat, and occupy less than half the sides of the head.

Mandibles heavily striated, with two large apical and three smaller teeth. Clypeus with a short, broad, straight lobe. Funiculi reach the middle of the head. Head very shiny, with abundant small foveoli. Prothorax broader than its length in the midline, submarginate on the sides. Mesothorax broader than long, with blunt angle on the sides. Epinotum longer than broad, very convex transversely. Petiole with a trapezoidal node, which is broader behind than long. Postpetiole bell shaped, much broader than long. In profile the pro- and meso-thorax form a convex line above, which is separated by a deep depression from the very convex epinotum. The node in profile longer than high, subtriangular, with rounded summit.

The whole body shiny; thorax and petiole finely punctate, postpetiole and gaster smooth; with relatively abundant erect hairs especially on the pedicel and moderately abundant pubescence, more dense on the thorax and gaster. The coxæ and femora are infuscated.

Type locality: Mouth of Jerume, British Guiana. 
Pseudomyrma sabanica var. saffordi var. nov.

Worker.

Length 3.4-4 mm. Head slightly longer than broad, with convex sides and excavated posterior edge. The mandibles are microscopically punctate and shiny; clypeal lobe as in P. belti. The eyes are flatter than in the latter and the head is much denser punctate. The prothorax is sharply marginate on the sides. The mesonotal disc is longer than broad, with a straight posterior border. The epinotum is length-oval, broadest at the level of the stigmata. The petiole from above is fully twice as long as broad, and somewhat triangular, with a rather long and broad peduncle. The thorax is evenly convex in profile, but with a saddle shaped impression between meso- and epinotum. The petiole is shaped as in belti bequarti in profile, but longer.

Erect hairs very sparse on the body, but the pubescence is more abundant, very fine, white and adpressed. The whole body, except the head lucid. Color brown and uniform, not bicolored.

Type locality: Yerba Santa, Chiapas (N. C. Collins).

The new subspecies is close to $P$. sabanica from which it differs by its lighter brown color and other points.

Cotype 20437, Harvard Collection, 20 specimens.

\section{Pseudomyrma santschii sp. nov.}

Worker.

Head almost as broad as long, narrowed behind, with slightly convex sides, almost completely taken up by the very large eyes; slightly excised behind. Mandibles with two large apical and several smaller teeth, all black; heavily striated. Clypeal lobe rectangular with straight anterior border. Head above with very fine punctation and fine pubescence, opaque; yellow with a dark brown spot around the ocelli. Thorax sharply marginate, deeply impressed between meso- and epinotum. With very fine long hairs and abundant and very fine pubescence. Pedicel from above similar to that of $P$. gracilis. Postpetiole and gaster slender with abundant pubescence. Thorax and legs brown except for yellow patches especially on the sutures and articulations of the legs; pedicel and gaster yellow. The dorsal part of the gaster is covered with many small sharply circumscribed brown spots, having the appearance of freckles. This is a very characteristic feature and distinguishes this ant from all other known Pseudomyrma. Size 8-9 mm. 
Type locality: Lima, Peru.

The new species is closely related to $P$. gracilis with which it has many features in common. All members of the gracilis group however have at least a part of the body black or very dark brown, while in the new form the dominant color is reddish brown. The freckled abdomen sets the new species aside from the numerous other forms related to $P$. gracilis.

Holotype No. 80, Haskins Collection; 3 Paratypes.

Pseudomyrma sericea var. acaciorum var. nov.

Worker.

Length 3.5-3.8 mm. Smaller than the other described form of sericea except the variety vineni Forel. Color chocolate brown, with the anterior part of the head, scapes and tarsi yellow; the funiculi, tibiæ and sides of the prothorax brownish yellow. The clypeal lobe is rounded-triangular as in the variety cordice. The base of the epinotum forms a square with rounded corners, and is shorter than the declivity. The fine hairs on the pronotal angle, and on the nodal angle (one on each side) are as in the other sericea and seem to be characteristic of the species.

Type locality: Tumba Muerto Road, Canal Zone. Living in Acacia spadicigera.

The new variety differs from all others by its color pattern, structure of the epinotum and pedicel in profile.

Described from a specimen labelled cotype 22865 , in the Harvard Collection, 21 specimens.

Pseudomyrma sericea var. lisa var. nov.

Worker.

The new variety agrees very closely in stature and even in coloration with $P$. sericea var. acaciorum which lives on Acacia spadicigera.

It differs from the latter by its slightly smaller size and color pattern. P. lisa has a beautiful color, deep lustrous brown and golden yellow. The yellow portions are: mandibles, clypeus, cheeks, antennæ, pronotum, legs and pedicel; the pronotum has two small dorsal spots; other light brown spots or areas are on the sides of the prothorax, upper coxæ, central part of the femora and a small triangle on the petiole, between the characteristic backward directed spines. The deep brown areas are bordered with yellow on the mesonotum and on the declivity of the epinotum. 
$P$. sericea var. lisa is probably only a local variety of acaciorum. The sides of the thorax are smooth in lisa (punctate in acaciorum).

Type locality: Peru.

Holotype No. 78, Haskins Collection.

Pseudomyrma spinolæ var. infernalis var. nov.

Worker.

Length $4.5 \mathrm{~mm}$. Larger than the var. convarians. Color brownish yellow, with the gaster a little darker, barely missing being bicolored. The type is more reddish, as is the var. gaigei. Mandibles pale yellow with five strong teeth. Head finely punctate and opaque. Prothorax evenly rounded, not marginate, as broad as long in the midline. The node from above is subtrianglar, approaching trapezoidal shape.

Female.

Length $5-5.5 \mathrm{~mm}$. Head and pedicel very much longer than in the worker. The thorax, except prothorax, brown, as the gaster. The latter opaque (shiny in the worker).

Male.

Length $5 \mathrm{~mm}$. Much darker than the other castes, with a very long and slender pedicel.

Type locality: Red Tank, Canal Zone. Taken from an Acacia spadicigera. Other specimens were taken by Prof. Banks at Cambia, Canal Zone. The latter are more slender, with more reddish color and they approach the type in the weaker margination of the prothorax.

The new variety differs from the type by lack of margination on the prothorax; from convarians by larger size; from gaigei by the narrower postpetiole and from atrox by the non-notched clypeal lobe.

Gynotype No. 100, Haskins Collection. Androtype No. 100A, Haskins Collection.

Described from cotype 20547, Harvard Collection, many workers.

Pseudomyrma spinolæ var. scelerosa var. nov.

Worker.

Length $4 \mathrm{~mm}$. Differs from all other forms of the spinolæ group by lacking all traces of bicoloration. The body is uniformly bright reddish yellow with the mandibles barely lighter colored. The whole body is opaque. The clypeal lobe is straight 
as in the variety infernalis. The prothorax lacks all traces of margination. The mesonotal disc is conspicuously elevated.

Type locality: Granada, Nicaragua. (Baker Coll.).

The new variety is closest to the variety infernalis from which it differs by the coloration, elevated mesonotal disc and the more pronounced sculpture.

Cotype No. 101, 3 workers in the Haskins Collection.

Described from specimens marked cotype 23145, in the Harvard Collection.

Pseudomyrma tenuis var. andina var. nov.

Worker.

Length $5 \mathrm{~mm}$. Identical with the type except for the coloration, which is reddish yellow as in the variety paranensis. The node is spined as in the type but the margins are sharper and the spines longer. The sculpture on the thorax is much coarser than in the type and consists of coarse punctures (fine punctation in the type). The head is a little broader in the new variety.

Type locality: Lima, Peru. From an unnamed tree.

Cotype No. 69, Haskins Collection; one pin has been deposited in the Museum of Comparative Zoölogy and is labelled Cotype 26814.

Pseudomyrma tenuis var. guatemalensis var. nov.

Worker.

Length $6 \mathrm{~mm}$. Color reddish yellow with the head brownish yellow. More robust than the type; both the pro- and mesothorax broader than long; node without either angles or spines behind, which distinguishes this variety from all others; the margin of the node is sharply raised and is brownish, contrasting sharply with the bright yellow color of the sunken portion of the node from above.

Type locality: Esquintla, Guatemala.

Cotype No. 70, Haskins Collection.

Pseudomyrma triplaridis Forel. 1904, Zool. Jb. Syst., 20, 684, all castes.

Worker.

Redescribed for the purpose of illustrating characters which can be used in separating the newly described subspecies. Length $4.5-4.8 \mathrm{~mm}$. Head $11 / 3$ times as long as broad, with 
nearly straight sides and weakly concave posterior border. The eyes are more than $1 / 3$ but less than $1 / 2$ the length of the sides of the head. The mandibles are striate and not lighter colored than the rest of the head. Clypeal lobe straight in front. The scapes are short and thick and fail to reach the middle of the eyes. Antennal joints 3-7 very transverse. Head strongly punctate and opaque. The prothorax is considerably longer than broad and submarginate. The disc not semicircular in front but with a rounded angle; it is semicircular behind and separated from the epinotal base by a wide margin. The latter is suboblong of the same width most of its length, concave in front. The petiolar node is subhexagonal with rounded corners. The postpetiole is broader than long and nodiform. The gaster is slender, with subparallel sides. In profile the thorax is weakly concave above with a strong depression at the mesepinotal suture. The convex epinotal base is rounded into the short declivity.

Head opaque, rest of the body subopaque. The pilosity is abundant, erect and of golden color. The pubescence is short and untidy; longer and more regular on the gaster, giving the latter a silky appearance.

Habitat: The specimens from which the description was made were collected by N. A. Weber in Venezuela, at the mouth of the Orinoco. The identification was made by Weber. The type locality is Amazonas.

Pseudomyrma triplaridis subsp. biolleyi subsp. nov.

Worker.

Length 4.8-5.2 mm. Head barely longer than broad, with convex sides, well rounded occipital corners and concave occipital edge. The eyes are smaller than in the type, about $1 / 3$ the size of the head, and flat. The mandibles are not paler than the head. (As in the type). The clypeal lobe is longer, and a little convex in front. The antennæ are similar to those of the type. Head finely punctate and very shiny. Prothorax broader than its length in the midline, evenly convex and very smooth. Disc semicircular in front (angular in the type). The epinotal base is longer than broad, broadest at the level of the stigmata, the part in front of that level is subtrapezoidal; the part behind that level gradually narrows towards the junction with the base. The petiolar node is globular above (as in some arboris-sanctee 
forms) and the pedicel is as broad as in latinoda. Postpetiole and gaster similar to the type. In profile the thorax is strongly impressed at the mesepinotal suture; the base and declivity are of the same length and form a blunt angle. The petiole has a strong antro-ventral tooth and a lamella. Pilosity and pubescence much less than in the type. The new variety is distinctly bicolored. The head is dark reddish brown, the gaster brown, except for the first segment which is reddish or reddish yellow, as is the rest of the body. The mesonotal disc is brownish.

Type locality: Kartabo, British Guiana (Wheeler Coll.).

Cotypes: No. 20648, Museum Comp. Zoöl.

Pseudomyrma triplaridis subsp. boxi subsp. nov.

Worker.

Length $4 \mathrm{~mm}$. Head 11/4 times as long as broad, with convex sides, well rounded posterior corners and concave occipital edge. The mandibles are not darker than the rest of the head, which is characteristic of all forms of $P$. triplaridis. The clypeal lobe is long, narrow and straight in front. Head strongly punctate and opaque. The scapes reach the middle of the eyes, which are slightly larger than $1 / 3$ the sides of the head. Prothorax as long as broad, well rounded, not marginate, strongly foveolate. The anterior rim of the mesonotal disc is semicircular. Epinotum longer than broad, broader at the level of the stigmata, strongly sculptured. Petiolar node shaped as in the subspecies biolleyi, with a very broad peduncle. Postpetiole and gaster stout, more convex and more robust than in the type.

Pilosity and pubescence abundant, but less than in the type. Color brownish yellow, antennæ, gaster and tibiæ a shade lighter.

Type locality: Blairmont, Berbice, British Guiana (H. E. Box coll.).

The new subspecies differs from the type and the ss biolleyi by its strong sculpture, different color and other characters.

Described from cotype 23146, Harvard University Collection, many workers.

Pseudomyrma triplaridis subsp. trigona subsp. nov.

Worker.

Length 4-4.8 mm. Head subrectangular. $11 / 3$ times as long as broad, with weakly convex sides and relatively sharp occipi- 
tal corners. The clypeal lobe is short and narrow and has a convex anterior border. Scapes short, not attaining the middle of the eyes, which are a little more than $1 / 3$ the sides of the head and long and flat. Head densely punctate and subopaque. Prothorax longer than broad, distinctly margined at the sides; mesonotal disc angular in front as in the type. Epinotum ovoid and convex. Petiolar node subhexagonal. Postpetiole broader than long. The gaster is shaped as in the type. Petiole in profile with a strong antero-ventral tooth; the lamina below not crenulated.

Pilosity and pubescence considerably less than in the type. The color is uniformly red; in the immature specimens reddish yellow.

Type locality: Blairmont, Berdice, British Guiana (Box Coll.).

The differences between the new subspecies and the others are given in the key.

Described from type 23147, Harvard University Collection.

Pseudomyrma voytowskii sp. nov.

Worker.

Head longer than broad, with parallel sides, the eyes occupying more than half the length of the sides. Mandibles white, smooth, with two larger apical teeth and some smaller ones. Scapes slender and short, not quite reaching the middle of the eyes. The whole head smooth, shiny and yellow except for a region on the occiput, which appears brownish; this is caused by the fact that the integument is transparent like a window, revealing the insides of the head. Prothorax not marginate, smooth and yellow. The mesonotal disc is a rounded triangle. Mesothorax and epinotum dark reddish brown, smooth, shiny on top, with heavy punctation on the sides. Pelicel in profile shaped as in tenuissima, with the anterior and posterior faces of equal slope; heavily punctate and devoid of ventral carina and ventral tooth. Postpetiole nodular in profile, with less coarse sculpture. Gaster stubby, smooth and very shiny. Petiole from above shaped as in subtillissima, subtriangular and very shiny.

Color. Distinctly bicolored, with the anterior part of the head and the prothorax yellow. The rest of the body dark brown, appendages lighter brown. Pilosity nearly absent, hav- 
ing but three to four long hairs on the gaster, and with the pubescence so short and sparse that only careful observation reveals its presence in a few spots. Size $2.2 \mathrm{~mm}$., including the mandibles.

Type locality: Lima, Peru.

The new species is related to $P$. subtillissima. It differs from tenuissima by the broader head and thorax, from the type by the almost complete absence of hairs, and from the var. andina by sculpture and other characters.

Holotype No. 77, Haskins Collection.

Pseudomyrma voytowskii var. costaricensis var. nov.

Worker.

Larger than the type; length $4.2 \mathrm{~mm}$. Of the same general appearance as $P$. voytowskii and with a similar color pattern. The head is very dark reddish brown, with the mandibles, clypeus and antennæ yellow. The scapes are browned in the middle. The head is subopaque (shiny in the type). The pilosity is more abundant in the type.

Type locality: San Jose, Costa Rica (Wheeler Coll.).

Holotype No. 87, Haskins Collection.

Worker.

Pseudomyrma weberi sp. nov.

Described from specimens in the Harvard Collection, erroneously labelled "subsp. of P. caroli."

The new species belongs to the branch Apedunculata which has a short petiole; it is near P. allidora and P. acanthobia. Length 3.8-4 mm. Weakly bicolored. Head dark reddish brown; mandibles, clypeus and antennæ yellow brown. Head subrectangular, $11 / 3$ times as long as broad, with slightly convex sides and convex posterior border. Eyes occupying less than half the sides of the head. Clypeal lobe narrow, relatively long and concave in front. Scapes reaching the middle of the head. Head finely punctate and a little shiny ( $P$. acanthobia has the head very concave behind and shiny; $P$. allidora has the head much longer, concave behind and very opaque). Prothorax longer than broad and not marginate (broader than long in acanthobia). The mesonotal disc is angulate in front (rounded in acanthobia, angulate in allidora). The epinotum is shaped as in allidora and is narrower behind; the anterior edge is straight (angulate in acanthobia, semicircular in allidora). 
The new species is readily separated from the more closely related species by the shape of the petiole in profile; weberi is the only species that has the posterior face of the peduncle concave; the antero-ventral tooth is very small and bears a single long hair.

Type locality: Esquintla, Guatemala.

Cotype 26815, Museum Comp. Zoöl., No. 88, Haskins Collection.

\section{Pseudomyrma wessoni sp. nov.}

Worker.

Length 3.5-4 mm. Head $1 \mathrm{x} / 4$ longer than broad with weakly convex sides and straight posterior border. The eyes occupy more than 2/3 the sides of the head. Mandibles pale yellow, longitudinally striated and opaque. Clypeal lobe with convex anterior border. Antennal scapes reach the middle of the eyes. Antennæ pale yellow, head darker yellow, very heavily punctate and opaque. Prothorax much longer than broad; margined and convex above. Mesothoracic disc convex. Epinotal base longer than broad, broadest at the level of the stigmata. Petiole from above triangular, with convex posterior edge, sharply margined. Postpetiole broader than long. Thorax in profile with very deep and broad mesepinotal depression; epinotal base much higher than the prothorax, convex, with a sharp angle at the declivity. Petiole in profile subtriangular, differing from all other species of the subgenus Apedunculata by its vertical posterior face. $P$. allidora has a similar petiole but the antero ventral tooth is blunt in the latter species, not sharp as in wessoni.

Color almost uniformly reddish yellow, with the tibiæ lighter. Pilosity short and sparse; pubescence relatively abundant, fine, silky and adpressed. Pedicel and gaster shiny, the rest opaque.

Type locality: Lima, Peru.

The new species is related to $P$. subtillissima, sericea, allidora, acanthobia and colei. It differs from each of these by the shape of the pedicel in profile, which is very short, with a vertical posterior face and a sharply recurved antero ventral tooth.

Female.

The female is of nearly the same size as the worker and with the same characters, except for the cast differences. There is a tendency to darker coloration; more brownish red, with an indication of bicoloration (the prothorax lighter brown than the rest of the thorax). 
Cotype No. 26816, Museum Comp. Zoöl., Gynotype No. 74, Haskins Collection.

Pseudomyrma wessoni var. tuberculata var. nov.

Worker.

Head about as broad as long with very large eyes, occupying more than half of the convex sides. Mandibles with two large apical teeth and several smaller ones, all brown; heavily striated; the clypeus with a sinusoid anterior border. Head and antennal scapes densely punctate and opaque. Prothorax marginate, deeply impressed mesepinotal suture and the epinotum with a faint indication of epinotal spines on the junction of the epinotal base and declivity. (This is a very unusual feature in workers of Pseudomyrma). Petiole in profile similar to that of wessoni, but shorter. Postpetiole very short and much broader than long. Abdomen stubby.

Coloration uniformly dark yellow or light brown. The pilosity consists of sparse long hairs. The pubescence is very fine and somewhat more abundant on the head and gaster.

Type locality: Lima, Peru.

The new variety is related to $P$. wessoni from which it differs by the structure of the pedicel, the small epinotal tubercles and the darker coloration. The sculpture is much as in the type.

Holotype No. 82, Haskins Collection.

Female.

Pseudomyrma wheeleri sp. nov.

Head almost twice as long as broad, with straight sides and the eyes occupying a little more than the middle third of the sides. Mandibles with two large apical teeth, a diastemma and two small basal teeth; heavily rugose, with stiff erect hairs. Clypeus with a rounded lobe. Scapes thickened, reaching a little beyond the anterior edges of the eyes. Whole head opaque, with dense punctation. Borders of clypeus and mandibles black. Thorax with fine punctation, opaque, with sparse long hair and medium dense pubescence. Petiole in profile about twice as long as high, without a peduncle, but with a short central carina which ends in a blunt tooth anteriorly; from above clavate in outline, with long stiff hairs. Heavily punctate and opaque. Wings sooty and with dense fine hairs. Gaster long and slender, with very fine punctation, a little shiny, with a few erect hairs 
and somewhat more abundant pubescence. Head, sides of the pronotum and all articulations, yellow. Rest of the body reddish brown. Length $8 \mathrm{~mm}$.

Type locality: Peru.

Male.

Head very short; eyes occupying the whole sides of the head. Mandibles short, finely striated, with a large apical and a few small basal teeth; with sparse and very long hairs. Clypeus with a projecting, circular lobe, prolonged backward between the antennal insertions. Frontal carinæ absent. Scapes so short that they form but elongate beads. Funiculi ten-jointed, with all joints of equal length and thickness. Occiput slightly sinusoid. Whole head densely punctate and opaque, bright yellow from the mandibles to the level of the antennal insertions, dark brown further back. Thorax of the usual shape; Mayrian furrow distinct, wings yellow and very hairy; very finely sculptured leaving the integument shiny; light brown, with all sutures yellow, petiole and postpetiole extraordinarily slender, the petiole thinned to a very slender stalk, with a slight swelling in the posterior third; with sparse long hairs and dense, coarse pubescence. Gaster very slender with dense pubescence. The petiole is unarmed below.

Bicolored, with part of the head dark brown, thorax lighter brown, the color gradually becoming lighter backward, gaster dark yellow.

Gynotype No. 79A, Androtype No. 79B, both in the Haskins Collection. 


\section{EXPLANATION OF PLATES}

Plate II

Showing the petioles from above of a representative series of Pseudomyrma.
1. excavata
13. decipiens
2. tenuis
3. nigropilosa
14. filiformis
4. gracilis
15. oculata
5. denticollis
16. sericea
6. sabanica
17. belti bequarti
7. elegans
18. canescens
8. championi
19. arboris-sanctoe
9. dolichopsis
20. bradleyi
10. kuenckeli
21. caroli
11. acanthobia
22. crenulata
12. brunnea var. nigrita

\section{Plate III}

Petioles in profile of a representative series of forms of Pseudomyrma.
1. excavata
13. acanthobia deliculata
2. tenuis
14. nigrocincta
3. tenuissima
15. flavidula
4. championi
16. weberi
5. denticollis
17. colei
6. sabanica
18. filiformis
7. spinicola
19. latinoda
8. dolichopsis
20. arboris-sanctoe
9. sericea acaciorum
21. picta humboldi
10. wessoni
22. canescens
11. sericea type
23. belti
12. elongata

\section{Plate IV}

Color patterns in Pseudomyrma gracilis (figs. 26-30); pedicels in profile (figs. 31-35) ; outline drawings of two newly described forms (figs. 24, 25).
24. acanthobia deliculata var. limai
25. wessoni var. tuberculata
26. gracilis subsp. sericata
27. gracilis subsp. carapuna
28. gracilis var. peruviana
29. gracilis subsp. mexicana
30. gracilis var. dimitiata
31. gracilis var. peruviana
32. gracilis var. squamifera
33. gracilis var. mexicana
34. gracilis var. maculata
35. gracilis type 


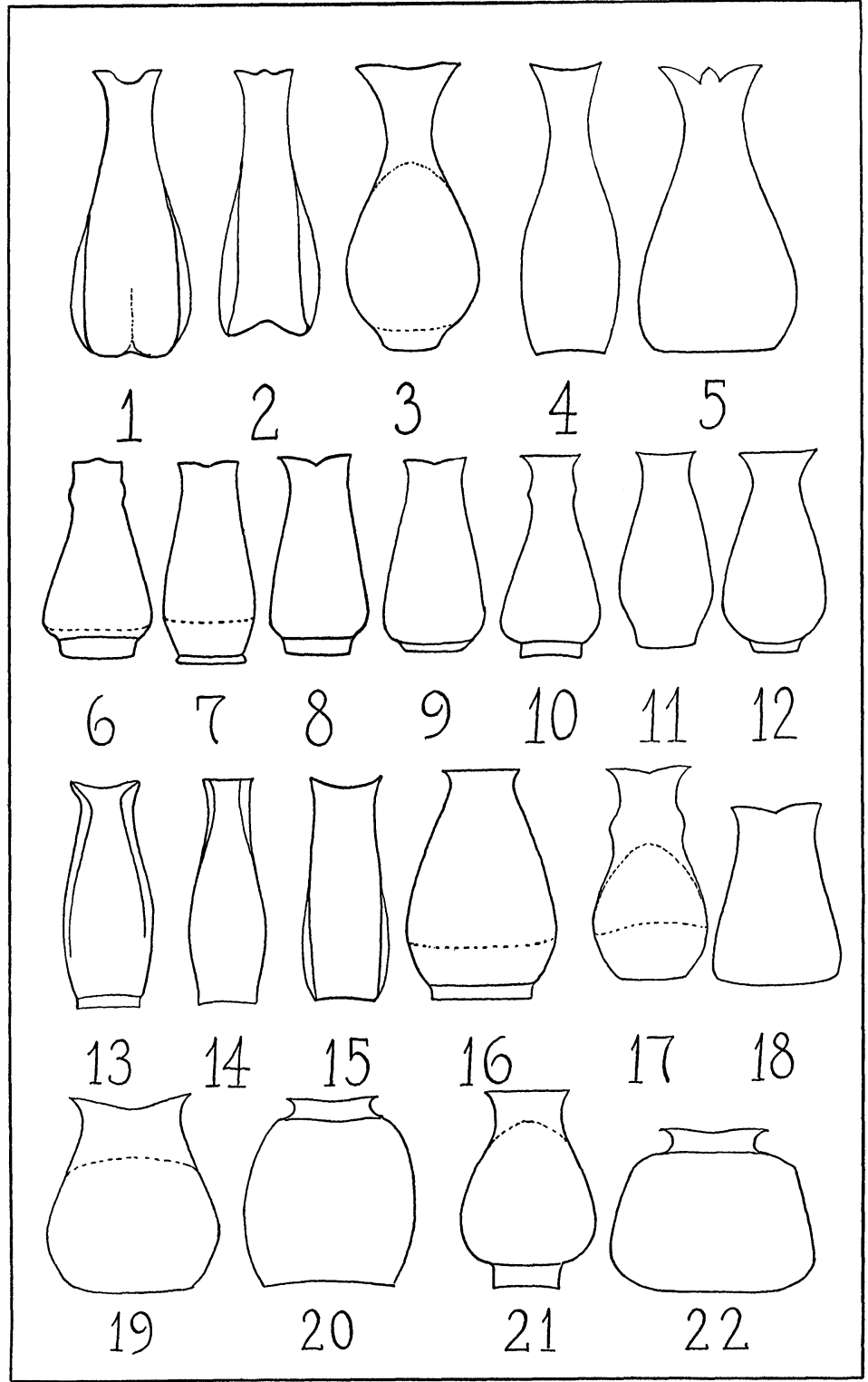




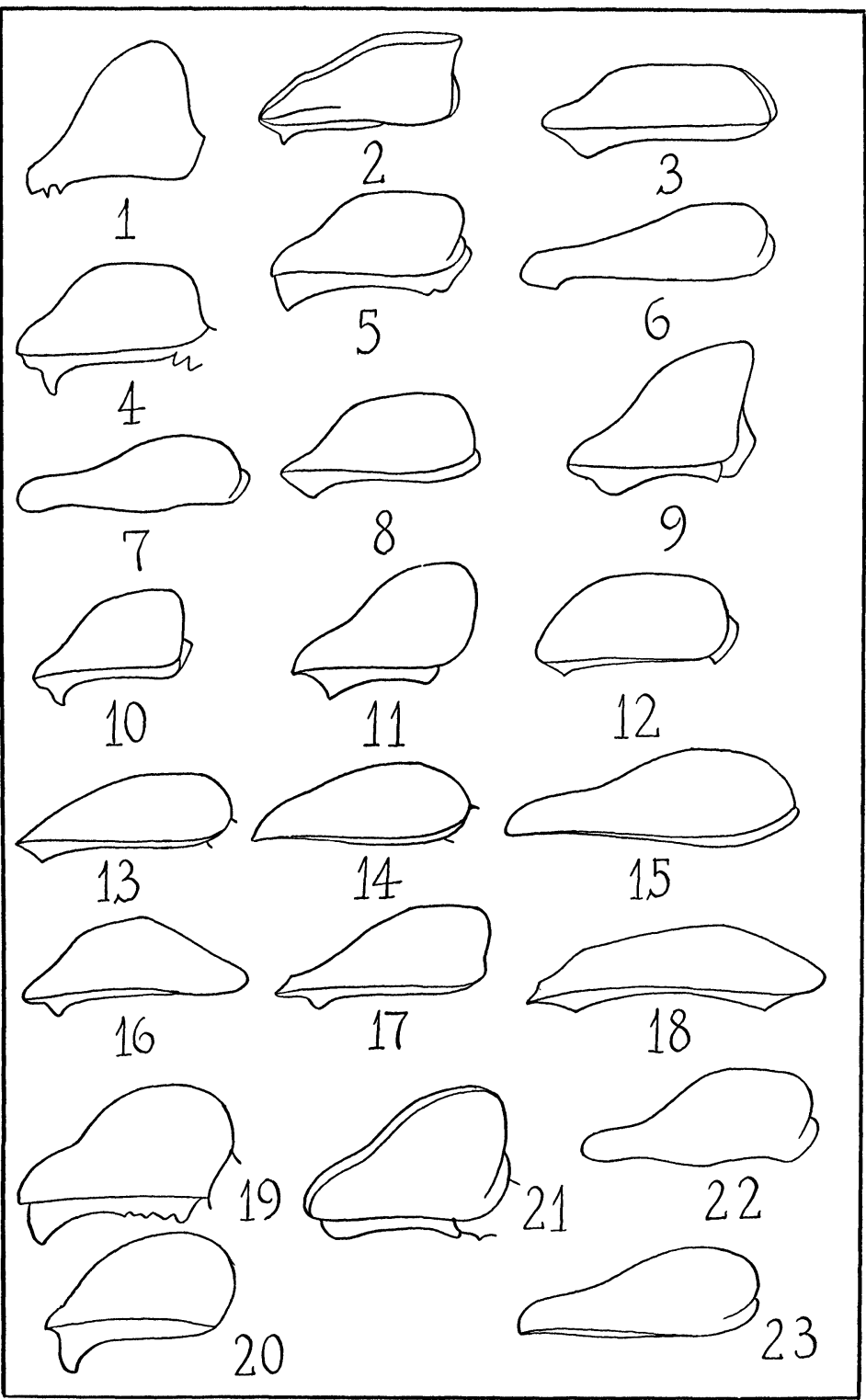






$\begin{array}{llllll}26 & 27 & 28 & 29 & 30 & 31\end{array}$





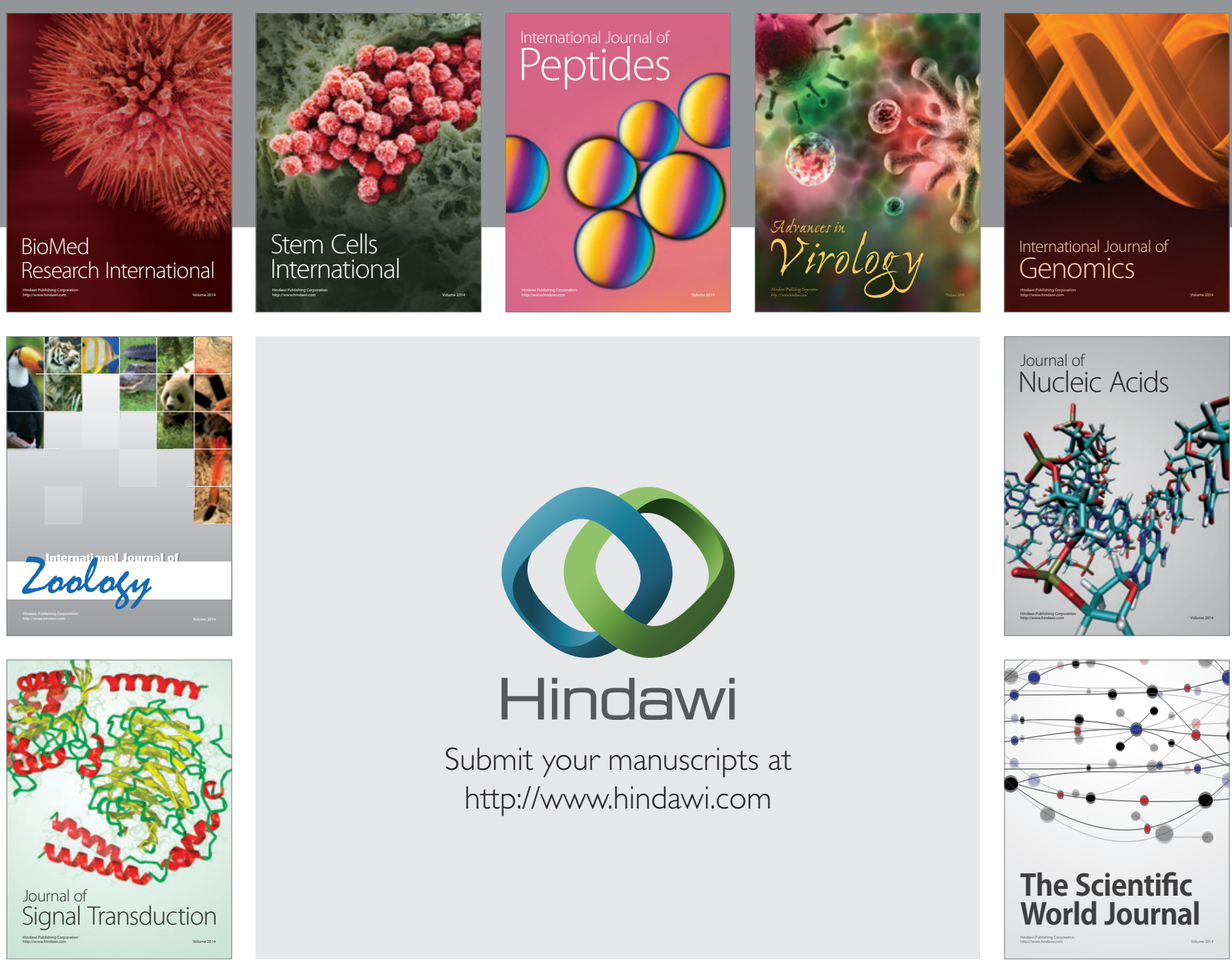

Submit your manuscripts at

http://www.hindawi.com
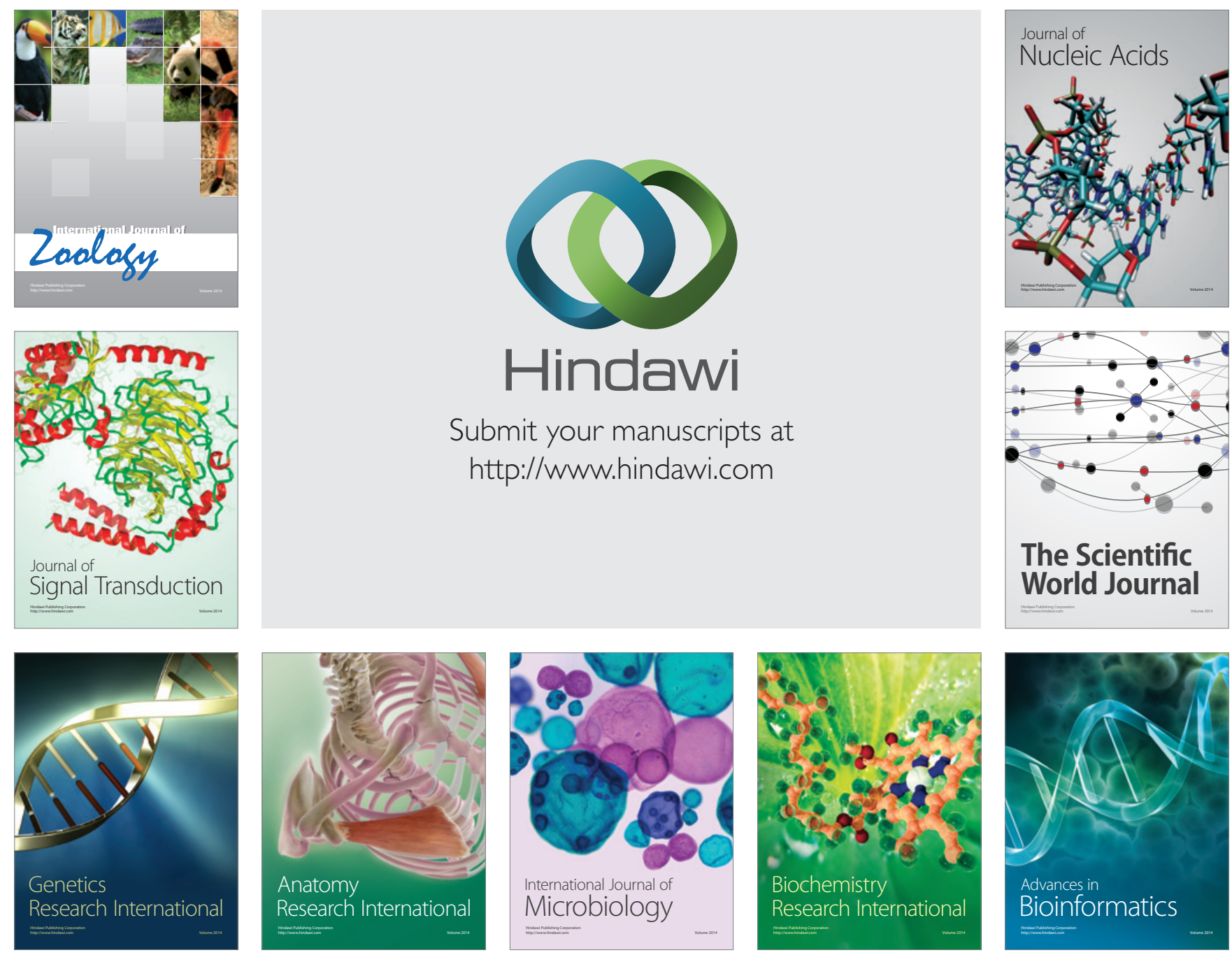

The Scientific World Journal
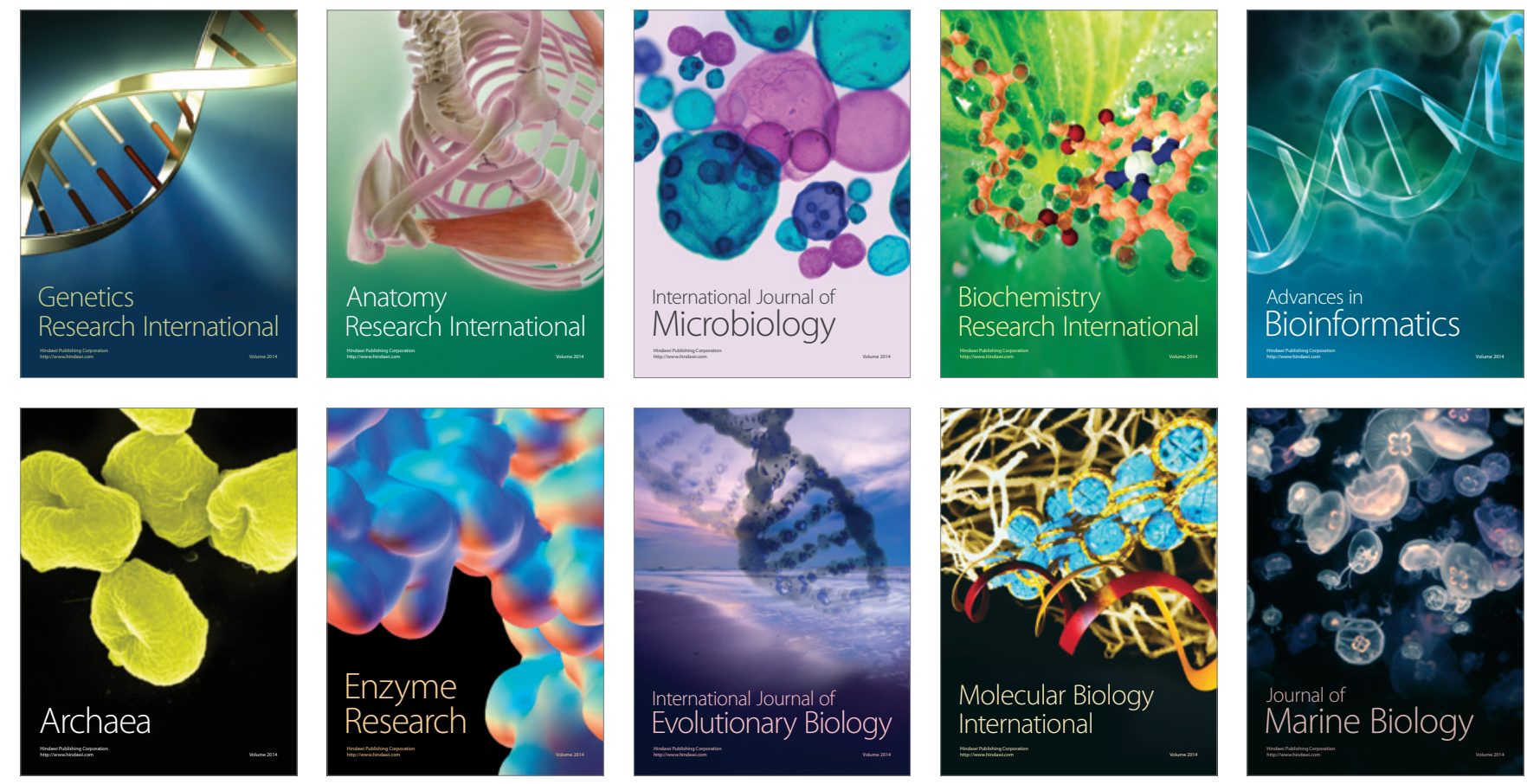